\title{
Optimalisasi program dan kegiatan Corporate Social Responsibility di Kota Bontang
}

\author{
Program optimization and Corporate Social Responsibility activities in Bontang \\ City
}

\author{
Septi Ariadi \\ Departemen Sosiologi, Fakultas Ilmu Sosial dan Ilmu Politik, Universitas Airlangga \\ E-mail: septi.ariadi@fisip.unair.ac.id
}

\begin{abstract}
Abstrak
Corporate Social Responsibility (CSR) memiliki peran yang strategis, bukan saja untuk menambah daya dan cakupan upaya penanganan kemiskinan dan pemberdayaan UMKM (Usaha Mikro Kecil Menengah), tetapi juga untuk mempercepat proses pemberdayaan masyarakat melalui dukungan program alternatif yang lebih kontekstual sesuai prakarsa atau inisiatif masyarakat miskin itu sendiri. Penelitian ini bertujuan untuk memetakan potensi perusahaan dalam upaya peningkatan kesejahteraan masyarakat di Kota Bontang, tetapi sekaligus juga merumuskan kebijakan dan program CSR yang benar-benar kontekstual dan efektif. Metode yang dilakukan adalah melakukan review terhadap berbagai kajian dan penelitian kondisi BUMN dan CSR, mengumpulkan dan melakukan analisis terhadap data terbaru tentang pelaksanaan program CSR di Kota Bontang, mengumpulkan dan melakukan analisis terhadap data primer yang digali langsung dari para warga masyarakat dan melakukan indept interview. Hasil dari penelitian ini berupa gagasan dan Strategi Optimalisasi Program CSR yang akan di lakukan di Kota Bontang guna untuk upaya penanggulangan kemiskinan. Kedepan, untuk mencegah agak tidak lagi terperosok pada kekeliruan yang serupa, dan upaya pemberdayaan masyarakat miskin di Kota Bontang melalui Program CSR benar-benar dapat berjalan efektif, maka yang dibutuhkan bukan sekadar kesediaan untuk melakukan introspeksi, tetapi juga revitalisasi program pemberdayaan masyarakat miskin yang benar-benar kontekstual dan berpihak kepada lapisan yang paling miskin khususnya para pelaku ekonomi kerakyatan. Kemudian ada stategi dan rekomendasi program CSR prioritas yang harus dilakukan sebagai upaya penanggulangan kemiskinan di Kota Bontang.
\end{abstract}

Kata kunci: pemberdayaan; alternatif; gagasan; strategi; miskin

\begin{abstract}
CSR has a strategic role, not only to increase the power and scope of efforts to overcome poverty and empower MSMEs (MSMEs), but also to accelerate the process of community empowerment through the support of more contextual alternative programs according to the initiatives or initiatives of the poor themselves. This study aims to map the company's potential in an effort to improve the welfare of the community in the City of Bontang, but at the same time also formulate CSR policies and programs that are truly contextual and effective. The method used is to review various studies and research on BUMN and CSR conditions, collect and analyze the latest data on the implementation of CSR programs in the City of Bontang, collect and analyze primary data collected directly from the community members and conduct indepth interviews. The results of this study are ideas and strategies for optimizing CSR programs that will be carried out in the city of Bontang in order to reduce poverty. In the future, to prevent a bit from falling into similar mistakes, and efforts to empower poor communities in the City of Bontang through CSR programs can really run effectively, then what is needed is not just a willingness to do introspection, but also revitalization of empowerment programs for poor people who are truly contextual and side with the poorest people, especially the people of the people's economy. Then there are strategies and recommendations of priority CSR programs that must be done as an effort to reduce poverty in the city of Bontang.
\end{abstract}


Keywords: empowerment; alternatives; ideas; strategi; poor.

\section{Pendahuluan}

Bagi Kota Bontang, salah satu sumber dana alternatif dan potensial untuk mempercepat upaya penanggulangan kemiskinan, meningkatkan taraf kesejahteraan masyarakat dan sekaligus mendorong pengembangan kegiatan ekonomi kerakyatan adalah Program CSR (Corporate Social Responsibility). Di tengah keterbatasan sumber dana pembangunan dari APBD dan APBN, keberadaan dan kehadiran CSR memiliki peran yang strategis, bukan saja untuk menambah daya dan cakupan upaya penanganan kemiskinan dan pemberdayaan UMKM (Usaha Mikro Kecil Menengah), tetapi juga untuk mempercepat proses pemberdayaan masyarakat melalui dukungan program alternatif yang lebih kontekstual sesuai prakarsa atau inisiatif masyarakat miskin itu sendiri.

Perusahaan memiliki tanggung jawab kepada para pemangku kepentingan agar dapat meminimalkan dampak negatif dan memaksimalkan dampak positif, mulai dari dampak sosial, ekonomi dan lingkungan. Corporate Sosial Responsibility (CSR) merupakan konsep lama sejak tahun 1953 dalam buku yang berjudul Social Responsibilities of Businessman karya Howard Bowen yang dikenal sebagai bapak CSR (Wibisono, 2007). Kemudian, ada beberapa konsep kemajuan perusahaan yaitu The Triple Bottom Line atau dikenal dengan 3P's Concept: Profit, People, dan Planet. Hal ini berarti perusahaan harus memperhatikan keuntungan (profit), tidak mengeksploitasi sumber daya, tetapi harus memperhatikan lingkungan (planet) dan juga kesejahteraan masyarakat (people) (Elkington, 1997).

Tidak hanya itu, perusahaan juga harus mempehatikan dalam pembuatan anggaran dana. Anggaran dana merupakan tanggung jawab setiap perusahaan, anggaran dana di buat sebagai bentuk formal dan tersusun secara sistematis dalam fungsi perencanaan, koordinasi, dan pengawasan (Sunyoto, 2012). Pengalokasian dana harus sesuai dengan kriteria yang disyaratkan agar meminimalkan kebocoran anggaran untuk sistem CSR sehingga tidak terjadi penganggaran dana yang berlebihan. Penurunan dana yang berlebih akan mengakibatkan penurunan Peranan CSR. Kemudian, untuk mewujudkan good corporate governance, good corporate citizenship dan good business ethics perusahaan tidak cukup hanya memikirkan kepentingan stakeholder, tetapi juga mempunyai orientasi untuk memenuhi kepentingan seluruh stakeholders (AmbaRao, 1993; Anderson, Jr., 1989; Kim, 2000; dan Raynard \& Forstater, 2002).

CSR pada dasarnya adalah bentuk kepedulian perusahaan yang menyisihkan sebagian keuntungannya (profit) bagi kepentingan pembangunan manusia (people) dan lingkungan (planet) secara berkelanjutan berdasarkan prosedur (procedure) yang tepat dan profesional (Suharto, 2007). CSR digagas dan dikembangkan berbagai perusahaan bukan sekadar untuk meningkatkan keuntungan perusahaan secara finansial, melainkan juga sebagai media untuk mengembangkan pembangunan sosial-ekonomi kawasan secara holistik, melembaga dan berkelanjutan.

Menurut ISO 26000, CSR adalah tanggung jawab sebuah organisasi terhadap dampak-dampak dari keputusan-keputusan dan kegiatan-kegiatannya pada masyarakat dan lingkungan yang diwujudkan dalam bentuk perilaku transparan dan etis yang sejalan dengan pembangunan berkelanjutan dan kesejahteraan masyarakat; mempertimbangkan harapan pemangku kepentingan, sejalan dengan hukum yang ditetapkan dan norma-norma perilaku internasional; serta terintegrasi dengan organisasi secara menyeluruh. Dalam pelaksanaannnya di lapangan, CSR biasanya mencakup tujuh komponen utama, yaitu: the environment, social development, human rights, organizational governance, labor practices, fair operating practices, dan consumer issues (Sukada \& Jalal, 2008).

Bagi sebagian pihak, CSR mungkin saja dipersepsi sebagai tambahan biaya bagi perusahaan dan karena itu membebani. Tetapi, bagi perusahaan yang lain, mereka umumnya menyadari bahwa yang namanya perusahaan tidak hanya mempunyai kewajiban-kewajiban ekonomis dan legal (artinya kepada pemegang 
saham atau shareholder), tetapi juga kewajiban-kewajiban sosial terhadap pihak-pihak lain yang berkepentingan (stakeholders) yang jangkauannya melebihi kewajiban-kewajiban ekonomi dan legal. Beberapa hal yang termasuk dalam CSR, antara lain adalah tatalaksana perusahaan (corporate governance) yang sekarang sedang marak di Indonesia, kesadaran perusahaan akan lingkungan, kondisi tempat kerja dan standar bagi karyawan, hubungan perusahan-masyarakat, dan investasi sosial perusahaan (corporate philantrophy).

Di Indonesia, tak terkecuali di Kota Bontang, istilah CSR sendiri harus diakui masih termasuk relatif baru, namun semakin populer digunakan sejak tahun 1990-an. Beberapa perusahaan di berbagai negara sebenarnya telah lama melakukan CSA (Corporate Social Activity) atau "aktivitas sosial perusahaan". Walaupun tidak menamainya sebagai CSR, secara faktual aksi dan berbagai kegiatan yang dikembangkan perusahaan dalam aktivitas sosialnya relatif mendekati konsep CSR yang merepresentasikan bentuk peran serta dan kepedulian perusahaan terhadap aspek sosial dan lingkungan. Sejak tahun 2003 Departemen Sosial tercatat sebagai lembaga pemerintah yang aktif dalam mengembangkan konsep CSR dan melakukan advokasi kepada berbagai perusahaan nasional.

Dalam berbagai kasus, CSR biasanya dilaksanakan secara langsung oleh perusahaan di bawah divisi human resource development atau public relations. CSR bisa pula dilakukan oleh yayasan yang dibentuk terpisah dari organisasi induk perusahaan namun tetap harus bertanggung jawab ke CEO atau ke dewan direksi. Pada awal kehadirannya, CSR umumnya lebih bertujuan dan menjadi bagian dari kepentingan kehumasan untuk membangun nama baik atau citra perusahaan.

Sebagian besar perusahaan di Indonesia menjalankan CSR melalui kerjasama dengan mitra lain, seperti LSM, perguruan tinggi atau lembaga konsultan. Beberapa perusahaan ada pula yang bergabung dalam sebuah konsorsium untuk secara bersama-sama menjalankan CSR. Beberapa perusahaan bahkan ada yang menjalankan kegiatan serupa CSR, meskipun tim dan programnya tidak secara jelas berbendera CSR (Suharto, 2007).

Pada awal perkembangannya, bentuk CSR yang paling umum dan populer dilakukan perusahaanperusahaan besar adalah pemberian bantuan bagi organisasi-organisasi lokal dan masyarakat miskin di negara-negara berkembang. Pendekatan CSR yang berdasarkan motivasi karitatif dan kemanusiaan ini pada umumnya dilakukan secara ad-hoc, partial, dan tidak melembaga. CSR pada tataran ini hanya sekadar do good dan to look good, berbuat baik agar terlihat baik. Perusahaan yang melakukannya termasuk dalam kategori "perusahaan impresif", yang lebih mementingkan "tebar pesona" (promosi) ketimbang "tebar karya" (pemberdayaan) (Suharto, 2008). Pelaksanaan Program CSR yang lebih banyak bersifat karitatif seperti ini, alih-alih memberdayakan masyarakat, CSR yang dikembangkan dalam kenyataan malah berubah menjadi candu (menimbulkan ketergantungan pada masyarakat), sandera (menjadi alat masyarakat memeras perusahaan) dan racun (merusak perusahaan dan masyarakat) (Suharto, 2008).

Dalam lima-sepuluh tahun terakhir, Program CSR yang sekadar tebar pesona dan sifatnya karitatif, dalam banyak kasus mulai kehilangan peminat dan pesonanya, serta makin banyak perusahaan yang kurang menyukai pendekatan karitatif semacam itu, karena dinilai tidak mampu meningkatkan keberdayaan atau kapasitas masyarakat lokal. Bahkan, dalam beberapa kasus, program CSR yang sifatnya karitatif ditengara hanya melahirkan ketergantungan, dan dalam jangka panjang justru bersifat kontra-produktif. Dalam perkembangannya kemudian, pelaksanaan CSR yang dilakukan berbagai perusahaan lebih banyak mengdopsi pendekatan community development karena dinilai lebih mendekati konsep empowerment dan sustainable development. Prinsip-prinsip good corporate governance, seperti fairness, transparency, accountability, dan responsibility kemudian menjadi pijakan untuk mengukur keberhasilan program CSR.

Di Indonesia, sejumlah perusahaan besar, seperti Holcim Indonesia Ltd, PT Unilever, Nestle, Sampoerna, Freeport, Pertamina serta perusahaan lainnya seperti PT Badak, PT Pupuk Kaltim di Kota Bontang, dan 
lain-lain telah cukup lama terlibat dalam menjalankan CSR. Kegiatan CSR yang dilakukan berbagai perusahaan, saat ini kita tahu telah berkembang sedemikian rupa, dan makin beragam, disesuaikan dengan kebutuhan masyarakat setempat berdasarkan needs assessment. Mulai dari pembangunan fasilitas pendidikan dan kesehatan, pemberian pinjaman modal bagi UKM, social forestry, penakaran kupu-kupu, pemberian beasiswa, penyuluhan HIV/AIDS, penguatan kearifan lokal, pengembangan skema perlindungan sosial berbasis masyarakat dan seterusnya. CSR pada tataran ini tidak sekadar do good dan to look good, melainkan pula to make good, menciptakan kebaikan atau meningkatkan kesejahteraan masyarakat (Suharto, 2008).

Apakah dengan melaksanaan program CSR, lantas selalu ada jaminan nama baik dan keuntungan bagi perusahaan? Untuk menjawab hal ini tentu bukan hal yang mudah. Dari hasil kajian yang dilakukan tiga lembaga internasional independen, Environics International (Kanada), Conference Board (AS), dan Prince of Wales Business Leader Forum (Inggris) yang melakukan survey tentang hubungan antara CSR dan citra perusahaan menemukan bahwa CSR ibaratnya adalah investasi keuntungan bagi perusahaan. Survey yang dilakukan terhadap 25 ribu konsumen di 23 negara yang dituangkan dalam The Millenium Poll on CSR pada tahun 1999 ini menunjukkan bahwa mayoritas responden (60\%) menyatakan bahwa CSR seperti etika bisnis, praktik sehat terhadap karyawan, dampak terhadap lingkungan, merupakan unsur utama mereka dalam menilai baik atau tidaknya suatu perusahaan. Sedangkan faktor fundamental bisnis, seperti kinerja keuangan, ukuran perusahaan, strategi perusahaan atau manajemen, hanya dipilih oleh $30 \%$ responden. Sebanyak 40\% responden bahkan mengancam akan "menghukum" perusahaan yang tidak melakukan CSR. Separo responden berjanji tidak akan mau membeli produk perusahaan yang mengabaikan CSR. Lebih jauh, mereka akan merekomendasikan hal ini kepada konsumen lain (lihat: Bisnis dan CSR, 2007: 88-90).

Di Indonesia, data riset dari majalah SWA terhadap 45 perusahaan menunjukkan bahwa CSR bermanfaat dalam memelihara dan meningkatkan citra perusahaan (37,38 persen), hubungan baik dengan masyarakat (16,82 persen), dan mendukung operasional perusahaan (10,28 persen). Di Indonesia, studi yang dilakukan PIRAC (2001) melaporkan bahwa dana program tanggungjawab sosial perusahaan (CSR) yang terkumpul paling-tidak mencapai lebih dari 115 milyar rupiah atau sekitar 11,5 juta dollar AS dari 180 perusahaan yang dibelanjakan untuk 279 kegiatan sosial yang direkam media massa. Ditambah berbagai kegiatan sosial lain yang tidak terdata secara resmi, besar kemungkinan dana yang telah disalurkan perusahaan untuk aktivitas sosial mereka jauh lebih besar lagi.

Berdasarkan pengamatan terhadap praktik CSR selama ini, diakui atau tidak, ternyata tidak semua perusahaan mampu menjalankan CSR sesuai filosofi dan konsep CSR yang sejati. Tidak sedikit perusahaan yang terjebak oleh bias-bias CSR berikut ini (Suharto, 2005; Suharto, 2008). Pertama, kecenderungan perusahaan untuk melakukan kamuflase. CSR yang dilakukan perusahaan tidak didasari oleh komitmen genuine, melainkan hanya untuk menutupi praktik bisnis yang memunculkan "ethical questions". Bagi perusahaan seperti ini, CD bukan kepanjangan dari Community Development, melainkan "Celana Dalam" yang berfungsi menutupi "aurat" perusahaan. McDonald's Corporation di AS dan pabrik sepatu Nike di Asia dan Afrika pernah tersandung kasus yang berkaitan dengan "unnecessary cruelty to animals" dan mempekerjakan anak di bawah umur.

Kedua, bersifat generik. Program CSR terlalu umum dan kurang fokus karena dikembangkan berdasarkan template atau program CSR yang telah dilakukan pihak lain. Perusahaan yang impulsif dan pelit biasanya malas melakukan inovasi dan cenderung melakukan "copy-paste" (kadang dengan sedikit modifikasi) terhadap model CSR yang dianggap mudah dan menguntungkan perusahaan. Ketiga, bersifat directive. Kebijakan dan program CSR dirumuskan secara top down dan hanya berdasarkan misi dan kepentingan perusahaan (shareholders) semata. Program CSR tidak partisipatif sesuai prinsip stakeholders engagement yang benar. 
Keempat, sekadar menjadi Lip Service. Artinya, Program CSR yang dilaksanakan tidak menjadi bagian dari strategi dan kebijakan perusahaan. Biasanya, program CSR tidak didahului oleh needs assessment dan hanya diberikan berdasarkan belas-kasihan (karitatif). Laporan tahunan CSR yang dibuat Enron dan British American Tobacco (BAT), misalnya, pernah menjadi sasaran kritik sebagai hanya "lip service" belaka. Kelima, hanya merupakan program Kiss and Run. Artinya, program CSR bersifat ad-hoc dan tidak berkelanjutan. Masyarakat diberi "ciuman" berupa barang, pelayanan atau pelatihan, lantas ditinggalkan begitu saja. Program yang dikembangkan umumnya bersifat myopic, berjangka pendek dan tidak memerhatikan makna pemberdayaan dan investasi sosial. CSR sekadar "menanam jagung", bukan "menanam jati".

Studi yang dilakukan LPPM Universitas Airlangga (2008) menemukan, bahwa dalam berbagai kasus pelaksanaan CSR yang dikembangkan perusahaan besar dan BUMN ternyata masih memiliki kekurangan. Program-program CSR yang dijalankan oleh perusahaan banyak yang hanya memiliki pengaruh jangka pendek dengan skala yang terbatas. Program-program CSR yang dilaksanakan seringkali kurang menyentuh akar permasalahan komunitas yang sesungguhnya. Seringkali pihak perusahaan masih menganggap dirinya sebagai pihak yang paling memahami kebutuhan komunitas, sementara komunitas dianggap sebagai kelompok pinggiran yang menderita, sehingga membutuhkan bantuan perusahaan. Di samping itu, aktivitas CSR dianggap hanya semata-mata dilakukan demi terciptanya reputasi perusahaan yang positif, bukan demi perbaikan kualitas hidup komunitas dalam jangka panjang. Studi ini berupaya untuk mendukung Pemerintah Kota Bontang dalam mempersiapkan fondasi bagi pelaksanaan program CSR yang benar-benar partisipatif dan efektif.

\section{Metode Penelitian}

Kegiatan ini pada dasarnya tidak hanya bertujuan untuk memetakan potensi perusahaan dalam upaya peningkatan kesejahteraan masyarakat di Kota Bontang, tetapi sekaligus juga merumuskan kebijakan dan program CSR yang benar-benar kontekstual dan efektif. Agar bisa diperoleh hasil yang benar-benar maksimal, secara rinci, langkah-langkah yang ditempuh dalam kegiatan ini adalah: pertama, melakukan review terhadap berbagai kajian dan penelitian tentang kondisi dan perkembangan BUMN dan kegiatan CSR yang biasa dikembangkan dunia industri. Review ini penting dilakukan untuk memperoleh gambaran tentang peran perusahaan dan BUMN dan perkembangan kegiatan CSR yang bermanfaat dalam mendukung upaya peningkatan kesejahteraan dan pemberdayaan kegiatan ekonomi masyarakat.

Kedua, mengumpulkan dan melakukan analisis terhadap data terbaru tentang pelaksanaan program CSR di Kota Bontang. Dalam kegiatan ini, pengumpulan data sekunder dilakukan dengan cara melacak data dari SKPD terkait, perusahaan, dan Badan Pusat Statistik Kota Bontang. Ketiga, mengumpulkan dan melakukan analisis terhadap data primer yang digali langsung dari para warga masyarakat yang menjadi target sasaran program CSR di Kota Bontang. Data primer digali dari masyarakat atau tepatnya keluarga-keluarga miskin yang selama ini menjadi kelompok sasaran Program CSR di berbagai kecamatan. Jumlah keluarga yang menjadi responden, ditetapkan sebanyak 600 keluarga. Lokasi penelitian ditetapkan di 3 kecamatan di Kota Bontang. Di masing-masing kecamatan jumlah keluarga yang diteliti ditetapkan sebanyak 200 keluarga. Keempat, dari 600 keluarga yang diteliti, dalam studi ini kemudian dipilih 60 keluarga yang dicoba diwawancarai secara mendalam (indepth interview), terutama menyangkut pola pemanfaatan dan akses mereka terhadap program CSR (rincian responden sebagaimana tertera pada Tabel 1. 
Tabel 1.

Lokasi dan Jumlah Responden

\begin{tabular}{ccc}
\hline Kecamatan & Keluarahan & Jumlah \\
\hline Bontang Selatan & Bontang Lestari & 65 \\
\cline { 2 - 3 } & Satimpo & 40 \\
\cline { 2 - 3 } & Berbas Pantai & 40 \\
\cline { 2 - 3 } & Berbas Tengah & 40 \\
\cline { 2 - 3 } & Tanjung Laut & 40 \\
\cline { 2 - 3 } & Tanjung Laut Indah & 15 \\
\cline { 2 - 3 } Bontang Utara & Bontang Kuala & 40 \\
\cline { 2 - 3 } & Bontang Baru & 40 \\
\cline { 2 - 3 } & Api-Api & 40 \\
\cline { 2 - 3 } & Gunung Elai & 40 \\
\cline { 2 - 3 } & Loktuan & 40 \\
\hline Bontang Barat & Guntung & 40 \\
& Kanaan & 40 \\
& Gunung Telihan & 40 \\
\cline { 2 - 3 } & Belimbing & 600 \\
\hline
\end{tabular}

Sumber: Data Primer

Seluruh data yang berhasil dikumpulkan, telah diolah dan dipadukan antara data kuantitatif dan data kualitatif yang diperoleh dari hasil in-depth interview. Di hasil akhir laporan, selain dirumuskan strategi untuk pengembangan Program CSR, juga diketengahkan rencana aksi yang dapat menjadi acuan bagi perusahaan dan BUMN dalam merumuskan arah pengelolaan dan pelaksanaan Program CSR yang benarbenar kontekstual dan efektif di tahun-tahun mendatang.

\section{Hasil dan Pembahasan}

\section{Masalah kemiskinan di Kota Bontang}

Menurut BPS, ada tiga ukuran dalam melihat kemiskinan di Kota Bontang. Pertama, Head Count Indeks (P0) yang biasa disebut sebagai indeks kemiskinan. Indeks ini menggambarkan persentase dari populasi yang hidup di dalam keluarga dengan pengeluaran konsumsi perkapita di bawah garis kemiskinan. Kedua, Poverty Gap Index (P1) atau biasa disebut juga indeks kedalaman kemiskinan. Indeks ini merupakan ukuran rata-rata kesenjangan pengeluaran/ pendapatan masing-masing penduduk miskin terhadap garis kemiskinan. Ketiga, Distributionally Sensitive Index (P2) atau biasa disebut indeks keparahan kemiskinan. Indeks ini dapat memberikan gambaran penyebaran pengeluaran di antara penduduk miskin dan dapat juga digunakan untuk mengetahui intensitas kemiskinan, sebagaimana tertera pada Tabel 2. 
Tabel 2.

Garis Kemiskinan, Penduduk Miskin dan Indeks Di Kota Bontang Tahun 2006-2014

\begin{tabular}{cccccc}
\hline Tahun & $\begin{array}{c}\text { Kemiskinan } \\
\text { (Ribu Rp/BIn) }\end{array}$ & Jiwa & $\%$ & $\begin{array}{c}\text { Indeks } \\
\text { Kedalaman } \\
\text { (P1) }\end{array}$ & $\begin{array}{c}\text { Indeks } \\
\text { Keparahan } \\
\text { (P2) }\end{array}$ \\
\hline 2006 & 194.687 & 9.854 & 7,86 & 2,14 & 0,73 \\
2007 & 215.107 & 9.803 & 7,87 & 0,52 & 0,25 \\
2008 & 240.748 & 9.540 & 7,26 & 2,71 & 0,42 \\
2009 & 285.402 & 9.034 & 6,66 & 1,05 & 0,37 \\
2010 & 313.718 & 9.402 & 6,67 & 0,88 & 0,20 \\
2011 & 347.312 & 8.122 & 5,47 & 0,56 & 0,20 \\
2012 & 383.200 & 8.114 & 5,34 & 0,69 & 0,12 \\
2013 & 422.951 & 8.153 & 5,23 & 0,79 & 0,19 \\
2014 & 465.740 & 8.104 & 5,08 & 0,88 & 0,17 \\
\hline
\end{tabular}

Sumber: Statistik Saku Kota Bontang Tahun 2015

Berdasarkan catatan BPS, dalam kurun waktu 2006 hingga 2014 jumlah penduduk miskin di Kota Bontang terus mengalami penurunan. Dalam tabel III.3 menunjukkan angka penduduk miskin pada tahun 2006 mencapai 9.854 jiwa atau 7,86\% dengan garis kemiskinan di bawah Rp194.687 per bulan dan pada tahun 2014 menjadi 8.104 jiwa atau 5,08\% dengan garis kemiskinan di bawah Rp.465.740 per bulan. Demikian dengan indeks kedalaman dan keparahan yang juga mengalami penurunan. Dengan diketahui adanya penurunan angka kemiskinan di Kota Bontang hal ini merupakan indikator positif keberhasilan Kota Bontang dalam upaya pengentasan kemiskinan.

Dalam melihat indikator kemiskinan, BAPPENAS telah menentukan tujuh indikator utama yaitu: Pertama, kurangnya pangan, sandang dan perumahan yang tidak layak. Kedua, terbetasnya kepemilikan tanah dan alat-alat produktif. Ketiga, kurangnya kemampuan membaca dan menulis. Keempat, kurangnya jaminan dan kesejahteraan hidup. Kelima, kerentanan dan keterpurukan dalam bidang sosial dan ekonomi. Keenam, ketakberdayaan atau daya tawar yang rendah. Ketujuh, akses terhadap ilmu pengetahuan yang terbatas, sebagaimana tertera pada Tabel 3. 
Tabel 3.

Rumah Tangga Menurut Kualitas Perumahan Tahun 2014

\begin{tabular}{|c|c|c|}
\hline Status Kepemilikan Rumah & Satuan & Jumlah \\
\hline Milik Sendiri & Persen & 61,87 \\
\hline Sewa & Persen & 27,20 \\
\hline Kontrak & Persen & 5,35 \\
\hline Lainnya & Persen & 5,58 \\
\hline Kondisi Perumahan & Satuan & Jumlah \\
\hline Rata-Rata Luas Lantai Yang Dikuasai Rumah & Persen & 85,64 \\
\hline Tangga $\left(\mathrm{M}^{2}\right)$ & Persen & 98,10 \\
\hline Rumah Tangga yang Beratap Seng, Asbes dan & Persen & 77,53 \\
\hline Genteng & Persen & 23,19 \\
\hline $\begin{array}{c}\text { Rumah Tangga Berpenghuni Berdiding Tembok } \\
\text { Rumah Tangga Berpenghuni Berdinding Kayu }\end{array}$ & Persen & 99,66 \\
\hline Rumah Tangga Berpenghuni Berlantai Bukan Tanah & & \\
\hline Sumber Air Minum & Satuan & Jumlah \\
\hline Air Kemasan/Isi Ulang & Rumah Tangga & 19.868 \\
\hline Leding Sampai Rumah & Rumah Tangga & 14.624 \\
\hline Leding Eceran & Rumah Tangga & 1.756 \\
\hline Pompa & Rumah Tangga & 1.192 \\
\hline Sumur Terlindungi & Rumah Tangga & 1.039 \\
\hline Sumur Tak Terlindungi & Rumah Tangga & 449 \\
\hline Mata Air Terlindungi & Rumah Tangga & 230 \\
\hline Mata Air Tak Terlindungi & Rumah Tangga & 103 \\
\hline Air Sungai, Air Hujan dan Lainnya & Rumah Tangga & 601 \\
\hline Fasilitas Buang Air Besar & Satuan & Jumlah \\
\hline Fasilitas Tempat BAB: & Rumah Tangga & 39.862 \\
\hline Sendiri & Rumah Tangga & 38.548 \\
\hline Bersama/Umum & Rumah Tangga & 1.092 \\
\hline Tidak Ada & Rumah Tangga & 222 \\
\hline Jenis Kloset: & Rumah Tangga & 39.862 \\
\hline Leher Angsa & Rumah Tangga & 38.709 \\
\hline Plengsengan & Rumah Tangga & 745 \\
\hline Cemplung/Cubluk & Rumah Tangga & 408 \\
\hline Tidak Pakai & Rumah Tangga & 0 \\
\hline Sumber Penerangan & Satuan & Jumlah \\
\hline Listrik PLN & Rumah Tangga & 37.856 \\
\hline Listrik Non PLN & Rumah Tangga & 1.910 \\
\hline Bukan Listrik & Rumah Tangga & 95 \\
\hline
\end{tabular}

Dilihat dari kualitas perumahan, sebanyak 61,87\% rumah tangga di Kota Bontang sudah memiliki Rumah sendiri. Sebanyak 27,20\% status kepemilikannya sewa, 5,35\% kontrak dan lainnya sebanyak 5,58\%. Adapun kondisi perumahan di Kota Bontang sebagian besar sudah memiliki lantai bukan tanah, beratapkan seng, asbes atau genteng serta berdinding tembok dan hanya 23,19\% yang masih berdinding kayu.

Untuk fasilitas $\mathrm{BAB}$, dari 39.862 rumah tangga sudah memiliki fasilitas BAB sendiri sebanyak 38.548 rumah tangga, 1.092 rumah tangga memanfaatkan fasilitas BAB bersama/umum dan 222 rumah tangga tidak ada fasilitas BAB. Untuk jenis kloset yang digunakan sebagian besar sudah menggunakan kloset jenis leher angsa, namun ada juga yang masih berupa plengsengan dan cemplung atau cublug.

Selain itu, kualitas perumahan juga dilihat dari jenis sumber air yang digunakan. Di Kota Bontang sudah tersedia sumber air bersih yang disalurkan kerumah-rumah penduduk, namun adapula rumah tangga di Kota Bontang yang masih belum bisa mengakses sumber air bersih sehingga mereka menggunakan sumur tak 
terlindungi sebanyak 449 rumah tangga sebagai sumber air untuk keperluan sehari-hari. Ada pula yang masih memanfaatkan mata air tak terlindungi sebanyak 103 rumah tangga, dan 601 rumah tangga memanfaatkan air sungai, air hujan dan sumber air lainnya. Sementara itu, untuk fasilitas penerangan sehari-hari ada sebanyak 37.856 rumah tangga yang sudah bisa mengakses listrik dari PLN dan 1.910 rumah tangga menggunakan listrik non PLN, listrik non PLN ini biasanya diperoleh dari panel-panel pembangkit listrik tenaga surya yang telah disediakan oleh pemerintah kota bontang dan 95 rumah tangga masih menggunakan pelita sebagai sumber penerangan sehari-hari.

Dari sisi tingkat pengeluaran per bulan, terbagi menjadi beberapa kelompok besaran pengeluaran. Dilihat pada tabel 4 maka besar pengeluaran rumah tangga di Kota Bontang dari tahun 2009 hingga 2014 terus mengalami peningkatan, hingga pada tahun 2014 jumlah pengeluaran rumah tangga per bulan pada kelompok pengeluaran $<500$ ribu menunjukkan angka nihil. Sementara pada kelompok di di atas $<500$ ribu jumlahnya justru terus meningkat dan jumlah pengeluaran terbesar adalah kelompok pengeluaan $>4.000 .000$ yang angkanya mencapai 12.756 rumah tangga, sebagaimana tertera pada tabel 4 .

Indikator lain dari kemiskinan adalah tingkat pendidikan penduduk Kota Bontang. Angka melek huruf di Kota Bontang pada tahun 2014 mencapai 99,26\% dan berdasarkan pendidikan tertinggi yang ditamatkan di Kota Bontang pada tahun 2014 sebagian besar merupakan tamatan SLTA/MA yaitu 42,10\%. Tamatan SLTP/MTs sebanyak 23,19\% sementara tamatan PT sebanyak 15,10\%. Untuk tamatan SD/MI sebesar 13,02 dan yang tidak sekolah sebanyak 6,59\%. Angka-angka tersebut menunjukkan pergeseran dimana jumlah tamatan sekolah pada jenjang yang lebih tinggi lebih besar serta mengalami peningkatan dari tahun ke tahun.

Tabel 4

Kelompok Pengeluaran Rumah Tangga per Bulan Kota Bontang, Tahun 2009-2014

\begin{tabular}{ccccccc}
\hline $\begin{array}{c}\text { Pengeluaran Ruta } \\
\text { Per Bulan (Ribu } \\
\text { Rupiah) }\end{array}$ & $\mathbf{2 0 0 9}$ & $\mathbf{2 0 1 0}$ & $\mathbf{2 0 1 1}$ & $\mathbf{2 0 1 2}$ & $\mathbf{2 0 1 3}$ & $\mathbf{2 0 1 4 p )}$ \\
\hline$<500$ & 73 & 78 & 0 & 0 & 0 & 0 \\
$500-999$ & 1.435 & 693 & 307 & 271 & 242 & 246 \\
$1000-1499$ & 5.090 & 3.467 & 969 & 331 & 336 & 342 \\
$1500-1999$ & 7.380 & 6.009 & 3.816 & 2.921 & 3.457 & 3.514 \\
$2000-2499$ & 5.373 & 6.009 & 7.868 & 6.116 & 6.328 & 6.423 \\
$2500-2999$ & 3.438 & 4.386 & 4.396 & 5.361 & 5.062 & 5.144 \\
$3000-3499$ & 2.367 & 3.619 & 4.291 & 5.734 & 6.169 & 6.268 \\
$3500-3999$ & 1.864 & 3.004 & 3.270 & 4.806 & 5.080 & 5.170 \\
$>4000$ & 9.678 & 9.780 & 12.494 & 12.432 & 12.554 & 12.756 \\
\hline Jumlah & 36.698 & 37.045 & 37.411 & 37.972 & 39.228 & 39.862 \\
\hline \multicolumn{7}{c}{ Sumber: Statistik Saku Kota Bontang Tahun 2015 }
\end{tabular}


Tabel 5.

Penduduk Usia 15 Tahun Keatas Menurut Kemampuan Membaca dan Pendidikan Tertinggi Yang Ditamatkan, Tahun 2000, 2010-2014

\begin{tabular}{|c|c|c|c|c|c|c|}
\hline Uraian & 2010 & 2010 & 2011 & 2012 & 2013 & $2014 p$ \\
\hline Melek Huruf (\%) & 96,25 & 99,20 & 99,21 & 99,22 & 99,25 & 99,26 \\
\hline a. Laki-laki & 96,41 & 99,31 & 99,27 & 99,32 & 99,32 & 99,33 \\
\hline b. Perempuan & 96,10 & 99,07 & 99,12 & 99,13 & 99,18 & 99,20 \\
\hline Pendidikan Teritinggi & 100,00 & 100,00 & 100,00 & 100,00 & 100,00 & 100,00 \\
\hline $\begin{array}{l}\text { a. Tidak/BIm } \\
\text { Tamat SD }\end{array}$ & 12,31 & 5,11 & 7,37 & 10,86 & 7,16 & 6,59 \\
\hline b. Tamat SD/MI & 22,48 & 17,88 & 15,25 & 13,73 & 12,96 & 13,02 \\
\hline $\begin{array}{l}\text { c. Tamat SLTP/ } \\
\text { MTs }\end{array}$ & 22,37 & 20,42 & 20,58 & 21,87 & 23,05 & 23,19 \\
\hline $\begin{array}{l}\text { d. Tamat SLTA/ } \\
\text { MA }\end{array}$ & 39,65 & 42,78 & 44,48 & 42,85 & 42,25 & 42,10 \\
\hline e. Tamat PT & 3,19 & 13,81 & 12,31 & 10,69 & 14,57 & 15,10 \\
\hline Rata-Rata Lama & 8,91 & 10,04 & 10,38 & 10,40 & 10,45 & 10,53 \\
\hline $\begin{array}{c}\text { Penduduk Usia } 15 \\
\text { Tahun }+\end{array}$ & 66,791 & 97,755 & 101,113 & 104.215 & 107.058 & 110.228 \\
\hline
\end{tabular}

Sumber: Statistik Saku Kota Bontang Tahun 2015

Adanya fasilitas sekolah gratis secara ekonomi telah memberi peluang bagi masyarakat untuk bisa mengenyam pendidikan hingga jenjang yang lebih tinggi. Akan tetapi masih ada faktor lain yang turut menghambat pemangunan dalam bidang pendidikan selama ini yang juga penting untuk diperhatikan yaitu faktor geografis dan budaya penduduk setempat, agar akses terhadap pendidikan bisa lebih merata dan terjangkau karena pentingnya pendidikan merupakan tiket untuk masyarakat miskin melakukan mobilitas vertikal. Tingginya pendidikan yang ditamatkan akan mempengaruhi keputusan seseorang untuk terlibat dalam aktifitas perekonomian. Selain itu, peluang kerja juga akan meningkat seiring dengan tingkat pendidikan seseorang dan di sisi lain pangsa pasar kerja sekarang lebih banyak membutuhkan tenaga kerja yang memiliki kemampuan teknis cukup memadai yang biasanya akan dipenuhi oleh mereka yang berpendidikan tinggi, sebagaimana ditunjukkan pada Tabel 5.

Dalam upaya pengentasan kemiskinan, program yang telah dilaksanakan oleh pemerintah Kota Bontang antara lain melalui PSE, PPLS, PKH, BLSM, BOS, Bedah Rumah dan program-program lainnya. Adapun jumlah Rumah Tangga yang menjadi sasaran PSE pada tahun 2005 sebanyak 35.020 jiwa dan dilanjutkan PPLS pada tahun 2008 hingga 2011. Pada tahun 2008 sasaran PPLS turun menjadi 30.859 dan pada tahun 2011 sasaran PPLS mengalami kenaikan menjadi 31.519 jiwa. Kenaikan jumlah sasaran PPLS pada tahun 2011 ini terjadi di wilayah Kecamatan Bontang Utara dan Bontang Barat (sebagaimana ditunjukkan Grafik $1)$.

Adanya PPLS ini telah membantu masyarakat miskin melalui pembagian raskin, sekolah gratis hingga jenjang SMA dan juga biaya kesehatan gratis. Adapun program jaminan kesehatan gratis di Kota Bontang meliputi Jamkesmas dan Jamkesprov. Pada tahun 2013 Jamkesmas di Kota Bontang telah berhasil memberikan pelayanan kepada 34.511 peserta dan Jamkesprov telah melayani 7.662 peserta. Keberadaan Jamkesmas maupun Jamkesprov bagi penduduk miskin di Kota Bontang ini sangat penting, karena secara ekonomi telah meringankan penduduk miskin dalam hal biaya pengobatan yang seringkali dianggap sebagai beban ekonomi, sehingga bila ada salah satu anggota keluarga miskin yang sakit mereka akan mengabaikan penyakit tersebut atau melakukan pengobatan seadanya. Dengan adanya Jamkesmas atau Jamkesprov maka setiap penduduk miskin bisa berobat ke rumah sakit bila ada anggota keluarga yang sakit, sebagaimana tertera pada grafik 2 . 


\section{Grafik 1.}

Jumlah Jiwa Rumah Tangga Sasaran PSE, dan PPLS, Tahun 2005, 2008, 2011 (Jiwa)

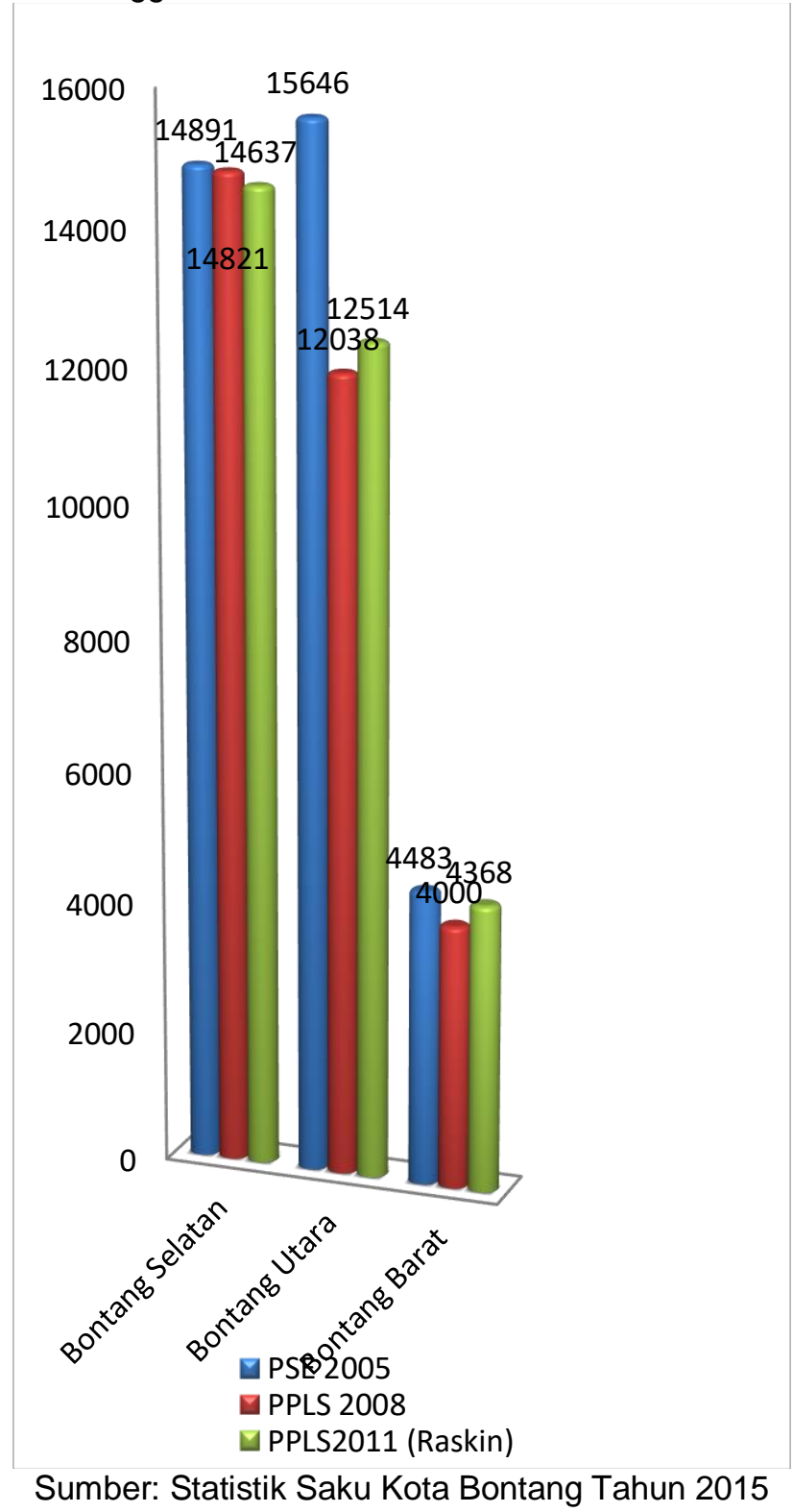

Adanya Program Perlindungan Sosial (PPLS) ini sangat membantu bagi keberadaan penduduk miskin karena secara ekonomi kebutuhan pokok seperti beras, pendidikan, kesehatan, rumah bisa terpenuhi. Akan tetapi, disamping pemerintah memberikan berbagai program bantuan akan lebih tepatnya lagi jika bantuan tersebut bisa membuat masyarakat mandiri, bukan sebaliknya justru menimbulkan ketergantungan masyarakat terhadap keberadaan bantuan dari pemerintah.

Merancang dan mengembangkan Program CSR, khususnya yang bertujuan untuk membantu mempercepat upaya penanggulangan kemiskinan di Kota Bontang harus diakui bukanlah hal yang mudah. Berharap persoalan kemiskinan dapat teratasi semata hanya dengan mengandalkan program-program CSR yang sifatnya karitatif, dan program-program darurat (emergency programme) yang hanya berdampak temporer, niscaya tidak akan pernah mencukupi. Lebih dari sekadar program yang populis, dan hanya bersifat tebar pesona, berbagai program CSR yang seyogianya dikembangkan berbagai perusahaan dan BUMN untuk 
membantu mempercepat upaya penanggulangan kemiskinan di Kota Bontang benar-benar harus dirancang dengan saksama (thoughtfully constructed), dan secara substansial menyentuh akar masalah yang sebenarnya dihadapi masyarakat miskin.

\section{Grafik 2}

Jumlah Peserta Jamkesmas dan Jamkesprov di Kota Bontang, Tahun 2010 dan 2013

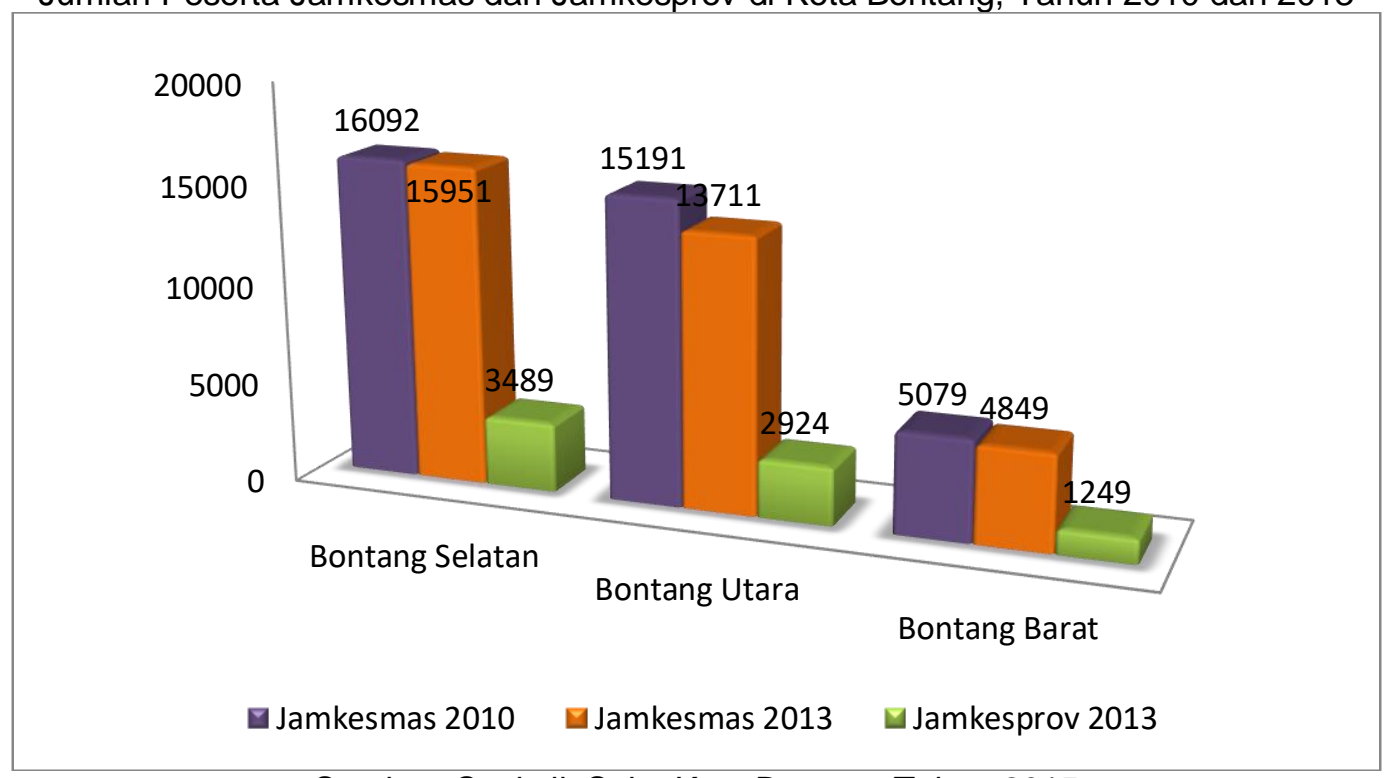

Sumber: Statistik Saku Kota Bontang Tahun 2015

\section{Menggagas program CSR ke depan}

Pengalaman selama ini telah banyak mengajarkan bahwa pelaksanaan berbagai program pemberdayaan masyarakat dan upaya penanggulangan kemiskinan yang digulirkan perusahaan dan BUMN seringkali tidak berjalan efektif, karena adanya sejumlah kekeliruan cara pandang perancang program pembangunan dalam memahami kemiskinan. Ketika program penanggulangan kemiskinan yang dirancang perusahaan dan BUMN semata hanya memandang kemiskinan sebagai fenomena single dimension semata sebagai masalah kekurangan pendapatan atau modal berusaha saja, maka dari situlah sebetulnya awal-mula terjadinya berbagai kegagalan yang terus terulang hingga sekarang.

Pengalaman di masa lalu juga telah banyak mengajarkan, bahwa program-program penanggulangan kemiskinan yang dilakukan hanya bersifat amal-karitatif dan berdasarkan pertimbangan logika produksi atau sekadar mengejar peningkatan omzet produksi, terlebih program yang sifatnya karitatif semata bukan saja menyebabkan terjadinya overs stock dan berhadapan dengan keterbatasan pangsa pasar. Tetapi, juga melahirkan proses marginalisasi dan ketergantungan penduduk miskin yang makin menyolok mata. Kelompok buruh, pekerja di sektor informal, pegawai rendahan, dan sejenisnya mereka umumnya makin tersisih, rawan diperlakukan salah, dan sulit dapat melakukan mobilitas vertikal karena struktur yang ada makin hari terasa makin tidak ramah.

Berdasarkan kajian yang telah dilakukan, beberapa kekeliruan dan kekurangan dari pelaksanaan program penanganan kemiskinan di masa lalu adalah: (1) Penduduk miskin cenderung diberlakukan sebagai kelompok yang homogen. Padahal mereka memiliki karakteristik, permasalahan dan kebutuhan yang berbeda-beda, yang tidak mungkin ditangani melalui proghram yang sifatnya top-down dan seragam; (2) Program yang dikembangkan lebih banyak bersifat darurat-penyelamatan yang justru beresiko mematikan potensi self-help penduduk miskin untuk menolong dirinya sendiri, dan (3) Program pemberdayaan usaha 
yang ditekuni masyarakat miskin lebih banyak berupa penyaluran bantuan modal usaha, tanpa memperhitungkan iklim persaingan usaha yang makin kompetitif dan daya beli masyarakat yang menurun.

Diakui atau tidak, selama ini berbagai program penanggulangan kemiskinan yang digulirkan --terutama dalam bentuk pemberian subsidi yang karitatif dan bantuan modal usaha atau pembinaan usaha produktif keluarga miskin-- seringkali masih terkonsentrasi pada rekayasa yang sifatnya teknis produksi dan cenderung hanya beriorientasi kuantitas, sehingga dalam banyak hal lebih menguntungkan kelompok masyarakat yang memiliki modal dan asset produksi yang berlebih.

Kebijakan pembangunan dan berbagai program penanggulangan kemiskinan yang dikembangkan seringkali kurang memperhatikan karakteristik dan konteks lokal masyarakat miskin, sehingga jangan heran jika yang terjadi kemudian adalah paket-paket kebijakan dan program yang bersifat meritokratis. Bisa dibayangkan, apa yang terjadi jika berbagai perusahaan dan BUMN mengucurkan sejumlah dana kepada masyarakat miskin tanpa terlebih dahulu mempertimbangkan struktur sosial di masyarakat lokal yang terpolarisasi atau paling-tidak terstratifikasi atas dasar berbagai demensi? Mungkinkah kelompok buruh nelayan atau nelayan miskin bisa meningkatkan kesejahteraannya jika paket-paket bantuan teknologi perikanan lebih diprioritaskan kepada nelayan pemilik atau juragan kapal yang dinilai lebih bisa dipercaya bakal tidak menunggak cicilan pinjamannya? Mungkinkah, anggota masyarakat miskin di lapisan yang paling miskin bisa memperoleh kesempatan memberdayakan dirinya, jika cara pandang terhadap mereka masih dipenuhi berbagai syakwasangka?

Ke depan, untuk mencegah agak tidak lagi terperosok pada kekeliruan yang serupa, dan upaya pemberdayaan masyarakat miskin di Kota Bontang melalui Program CSR benar-benar dapat berjalan efektif, maka yang dibutuhkan bukan sekadar kesediaan untuk melakukan introspeksi, tetapi juga revitalisasi program pemberdayaan masyarakat miskin yang benar-benar kontekstual dan berpihak kepada lapisan yang paling miskin khususnya para pelaku ekonomi kerakyatan.

\section{Strategi optimalisasi program CSR}

Dalam upaya pemberdayaan masyarakat miskin, khususnya mempercepat upaya penanggulangan kemiskinan di Kota Bontang, ke depan strategi pokok yang perlu dikembangkan perusahaan dan BUMN dalam pelaksanaan program CSR adalah sebagai berikut; Pertama, berkaitan dengan upaya peningkatan posisi tawar (bargaining position) masyarakat miskin melawan kekakuan (rigidity) dan sifat eksploitatif dari struktur yang membelenggu mereka. Artinya, program CSR yang dikembangkan seyogianya tidak hanya terjebak pada program-program yang sifatnya karitatif atau darurat-penyelamatan, melainkan harus lebih mengedepankan program-program yang berorientasi pada proses pemberdayaan, yang intinya bersifat people centered, participatory, empowering, dan sustainable.

Pemberdayaan pada intinya adalah pemanusiaan. Pemberdayaan, mengutamakan usaha sendiri dari orang yang diberdayakan untuk meraih keberdayaannya. Oleh karena itu, pemberdayaan sangat jauh dari konotasi ketergantungan. Dua hal yang menjadi prasyarat bagi upaya pemberdayaan adalah. Pertama, pembentukan kelompok (Pokmas) untuk memperkuat posisi bargaining penduduk miskin, khususnya dalam penentuan harga. Kedua, dalam bentuk pengembangan jaringan (net working) dan memperluas akses penduduk miskin terhadap pasar yang lebih luas.

Kedua, berkaitan dengan upaya mengurangi kadar kerentanan dan sekaligus bagaimana memperkuat penyangga sosial-ekonomi keluarga miskin. Dalam hal ini, salah satu hal yang dapat dikembangkan dalam Program CSR adalah bagaimana mendorong pengembangan kegiatan produktif alternatif keluarga miskin. Selama ini, kekurangan pokok yang perlu diperhatikan dari berbagai upaya pengentasan masyarakat miskin yang banyak dipraktekkan adalah bahwa mereka menjadi begitu memusatkan perhatian pada peningkatkan 
kuantitas produksi atau hasil kegiatan produktif masyarakat miskin, sehingga kebutuhan sistem produksi mendapat tempat yang lebih utama daripada kebutuhan masyarakat miskin yang lebih substansial.

Ke depan, untuk lebih menjamin efektivitas pelaksanaan program penanggulangan kemiskinan, maka seyogianya disadari bahwa meningkatkan kesejahteraan penduduk miskin sesungguhnya tidak selalu harus dengan cara memacu perkembangan dan semata hanya berusaha meningkatkan volume atau jumlah produksi sektor usaha kecil tersebut. Sebagai salah satu alternatif - dan mungkin juga dapat dilakukan secara bersamaan - pola lain yang dapat dilaksanakan untuk mengembangkan usaha kecil adalah dengan cara melakukan efisiensi proses produksi.

Selain itu, untuk meningkatkan kadar keberdayaan keluarga miskin dan sekaligus mencegah resiko kemungkinan terjadinya kegagalan total dari usaha keluarga miskin alangkah baiknya jika di saat yang bersamaan tiap-tiap anggota keluarga yang termasuk tenaga kerja produktif didorong untuk mengembangkan kegiatan usaha yang beraneka-ragam atau satu dengan yang lain saling berbeda. Pengalaman yang sudah-sudah membuktikan bahwa sebuah keluarga yang semata-mata hanya menggantungkan kepada satu matapencaharian - di mana suami, istri dan anak semua bekerja di sektor yang sama - umumnya secara sosial-ekonomi lebih rapuh karena jika suatu saat harga komoditi yang mereka produksi anjlok, maka itu berarti semua anggota keluarga akan kehilangan dan mengalami kerugian yang sama. Ini berbeda jika dalam sebuah keluarga, masing-masing anggota memiliki matapencaharian yang berbeda-beda. Keluarga yang mengembangkan pola diversifikasi usaha, terbukti dalam kehidupan sehari-hari mereka selalu lebih berdaya dan kenyal terhadap tekanan kebutuhan ekonomi.

Ketiga, berkaitan dengan upaya untuk memastikan pengembangan usaha keluarga miskin di Kota Bontang yang benar-benar berkelanjutan. Artinya, berbagai program CSR yang dikembangkan perusahaan dan BUMN bagi masyarakat miskin di Kota Bontang hendaknya berbasis pada upaya pengembangan investasi dan mengutamakan pengembangan UMKM yang berkelanjutan (sustainable). Pemberian bantuan kepada para pelaku UMKM seyogianya bukan hanya dalam bentuk modal usaha, tetapi juga dalam bentuk asset produksi yang sifatnya berkelanjutan. Berbeda dengan modal usaha yang habis untuk membeli bahan-bahan produksi, bantuan asset berbentuk alat produksi atau sarana usaha yang sifatnya lebih permanent. Misal: buruh konveksi diberi bantuan mesin jahit, tukang becak yang belum memiliki becak sendiri diberi bantuan becak, tukang ojek diberi bantuan sepeda motor dan lain sebagainya.

\section{Rekomendasi program CSR prioritas}

Mengingat problema yang dihadapi keluarga miskin di Kota Bontang tidak selalu sama satu dengan yang lain, maka Program CSR yang ditawarkan kepada keluarga miskin seyogianya tidak bersifat homogen dalam bentuk paket-paket bantuan yang ditentukan sepihak dari atas, melainkan berupa program bantuan yang sifatnya open menu. Yang dimaksud program open menu di sini adalah berupa tawaran aneka-ragam program yang disesuaikan dengan kebutuhan riil keluarga miskin secara bottom-up. Berbeda dengan dana pembangunan daerah yang acapkali kaku dan harus disesuaikan dengan nomenklatur yang ketat, alokasi dan pemanfaatan dana Program CSR umumnya lebih luwes atau fleksibel, sehingga sangaat memungkinkan untuk dikembangkan berbagai program alternatif yang benar-benar kontekstual, sebagaimana ditunjukkan pada tabel 6 . 
Tabel 6

Pilihan Program CSR Untuk Mempercepat Upaya Penanganan Kemiskinan di Kota Bontang

\begin{tabular}{|c|c|c|}
\hline Program & Tujuan & Target Sasaran \\
\hline $\begin{array}{c}\text { Bantuan sembako bagi } \\
\text { keluarga miskin tidak produktif }\end{array}$ & $\begin{array}{c}\text { Memperpanjang daya tahan } \\
\text { keluarga miskin menghadapi } \\
\text { tekanan kebutuhan hidup } \\
\text { sehari-hari }\end{array}$ & $\begin{array}{l}\text { Keluarga miskin } \\
\text { yang telah } \\
\text { diverifikasi }\end{array}$ \\
\hline $\begin{array}{l}\text { Perbaikan rumah keluarga } \\
\text { miskin yang tidak layak huni }\end{array}$ & $\begin{array}{c}\text { Memenuhi kebutuhan dasar } \\
\text { keluarga miskin agar dapat } \\
\text { hidup di rumah yang layak huni }\end{array}$ & $\begin{array}{l}\text { Keluarga miskin } \\
\text { yang memiliki rumah } \\
\text { tidak layak huni }\end{array}$ \\
\hline $\begin{array}{l}\text { Program "Padat Karya" untuk } \\
\text { pembangunan dan perbaikan } \\
\text { fasilitas publik }\end{array}$ & $\begin{array}{c}\text { Memberi peluang kerja temporer } \\
\text { kepada keluarga miskin di } \\
\text { musim paceklik, yang menjadi } \\
\text { korban PHK atau yang tidak } \\
\text { bekerja }\end{array}$ & $\begin{array}{c}\text { Anggota keluarga } \\
\text { miskin di usia } \\
\text { produktif yang tidak } \\
\text { bekerja/korban PHK }\end{array}$ \\
\hline $\begin{array}{l}\text { Bantuan beasiswa dan } \\
\text { peralatan sekolah bagi anak- } \\
\text { anak keluarga miskin }\end{array}$ & $\begin{array}{l}\text { Menjamin kelangsungan } \\
\text { pendidikan siswa miskin }\end{array}$ & $\begin{array}{l}\text { Siswa dari keluarga } \\
\text { miskin }\end{array}$ \\
\hline $\begin{array}{l}\text { Pengembangan program } \\
\text { Anak Asuh di kalangan } \\
\text { pegawai perusahaan/BUMN }\end{array}$ & $\begin{array}{l}\text { Menjamin kelangsungan } \\
\text { pendidikan siswa miskin }\end{array}$ & $\begin{array}{c}\text { Pegawai } \\
\text { perusahaan/BUMN } \\
\text { yang mendukung } \\
\text { gerakan anak asuh }\end{array}$ \\
\hline $\begin{array}{l}\text { Program Bimbel (Bimbingan } \\
\text { Belajar) untuk siswa dari } \\
\text { keluarga miskin }\end{array}$ & $\begin{array}{l}\text { Mencegah kemungkinan siswa } \\
\text { rawan DO putus sekolah di } \\
\text { tengah jalan }\end{array}$ & $\begin{array}{l}\text { Siswa miskin yang } \\
\text { berpotensi putus } \\
\text { sekolah (pernah } \\
\text { tidak naik kelas, } \\
\text { bukan siswa } \\
\text { berprestasi) } \\
\end{array}$ \\
\hline $\begin{array}{c}\text { Revitalisasi dan } \\
\text { Pengembangan Posyandu }\end{array}$ & $\begin{array}{l}\text { Meningkatkan peran Posyandu } \\
\text { dalam membantu pemeliharaan } \\
\text { kesehatan keluarga miskin }\end{array}$ & $\begin{array}{l}\text { Ibu hamil dan anak- } \\
\text { anak miskin }\end{array}$ \\
\hline $\begin{array}{c}\text { Bantuan sarana produksi } \\
\text { (aset) bagi keluarga miskin } \\
\text { pelaku UMKM }\end{array}$ & $\begin{array}{l}\text { Memperkuat fondasi usaha dan } \\
\text { menjamin kelangsungan usaha } \\
\text { yang ditekuni keluarga miskin }\end{array}$ & $\begin{array}{c}\text { Keluarga miskin } \\
\text { pelaku usaha mikro } \\
\text { dan kecil }\end{array}$ \\
\hline $\begin{array}{l}\text { Bantuan paket "modal usaha } \\
\text { ganda" untuk pasangan } \\
\text { suami-istri keluarga miskin }\end{array}$ & $\begin{array}{l}\text { Mendukung pengembangan } \\
\text { diversifikasi usaha keluarga } \\
\text { miskin }\end{array}$ & $\begin{array}{l}\text { Pasangan suami-istri } \\
\text { keluarga miskin }\end{array}$ \\
\hline $\begin{array}{l}\text { Pelatihan ketrampilan dan } \\
\text { manajemen usaha untuk } \\
\text { mendukung efisiensi proses } \\
\text { produksi, pengembangan } \\
\text { diversifikasi usaha dan } \\
\text { diversifikasi produk (kuliner, } \\
\text { jahit-menjahit dan } \\
\text { pertukangan) } \\
\end{array}$ & $\begin{array}{c}\text { Meningkatkan kemampuan atau } \\
\text { modal sosial keluarga miskin } \\
\text { dalam mengembangkan } \\
\text { usahanya }\end{array}$ & $\begin{array}{c}\text { Keluarga miskin } \\
\text { pelaku usaha mikro } \\
\text { dan kecil }\end{array}$ \\
\hline $\begin{array}{l}\text { Pengembangan usaha untuk } \\
\text { memperkuat penyangga } \\
\text { ekonomi keluarga miskin }\end{array}$ & $\begin{array}{c}\text { Memberi kesempatan keluarga } \\
\text { miskin meningkatkan } \\
\text { penghasilan sehari-hari }\end{array}$ & $\begin{array}{l}\text { Kaum perempuan } \\
\text { dari keluarga miskin }\end{array}$ \\
\hline $\begin{array}{l}\text { Pengembangan program } \\
\text { magang untuk tenaga } \\
\text { produktif anggota keluarga } \\
\text { miskin (lulusan SMK) }\end{array}$ & $\begin{array}{c}\text { Mengurangi angka } \\
\text { pengangguran di kalangan } \\
\text { keluarga miskin }\end{array}$ & $\begin{array}{l}\text { Siswa miskin lulusan } \\
\text { SMK/SMA }\end{array}$ \\
\hline
\end{tabular}




\begin{tabular}{ccc}
\hline $\begin{array}{c}\text { Pengembangan produk } \\
\text { olahan makanan dan } \\
\text { pertanian/perikanan berbasis } \\
\text { sumber daya lokal }\end{array}$ & $\begin{array}{c}\text { Meningkatkan nilai tambah } \\
\text { produk yang dihasilkan keluarga } \\
\text { miskin }\end{array}$ & $\begin{array}{c}\text { Keluarga miskin } \\
\text { pelaku usaha mikro } \\
\text { dan kecil }\end{array}$ \\
\hline $\begin{array}{c}\text { Pengembangan lembaga } \\
\text { kelompok masyarakat miskin } \\
\text { untuk mendukung kebutuhan } \\
\text { sosial-ekonomi keluarga } \\
\text { miskin (Posdaya, koperasi, dII) }\end{array}$ & $\begin{array}{c}\text { Mendukung pengembangan } \\
\text { institusi sosial yang mendukung } \\
\text { pemenuhan kebutuhan hidup } \\
\text { dan usaha keluarga miskin }\end{array}$ & Keluarga miskin \\
\hline $\begin{array}{c}\text { Perbaikan dan pembangunan } \\
\text { fasilitas kebersihan dan } \\
\text { kesehatan lingkungan } \\
\text { (sampah, air bersih, dll) }\end{array}$ & $\begin{array}{c}\text { Mendukung terciptanya } \\
\text { kelestarian lingkungan di } \\
\text { kantong-kantong kemiskinan }\end{array}$ & Keluarga miskin \\
\hline
\end{tabular}

Sumber: Data Primer

Program apa yang nantinya menjadi pilihan perusahaan dan BUMN untuk dikembangkan, sudah barang tentu tergantung kepada dukungan dana dan tujuan yang ingin dicapai perusahaan dan BUMN masingmasing. Yang terpenting, apa pun pilihan program yang akan dikenbangkan hendaknya tidak sekadar hanya berupa program amal-karitatif yang hanya berdampak sesaat, melainkan program yang benar-benar berorientasi pada upaya peningkatan keberdayaan dan posisi tawar keluarga miskin dalam mengembangkan potensi swakarsa mereka.

\section{Simpulan}

Berdasarkan kajian yang telah dilakukan, beberapa kekeliruan dan kekurangan dari pelaksanaan program penanganan kemiskinan di masa lalu adalah: (1) Penduduk miskin cenderung diberlakukan sebagai kelompok yang homogen. Padahal mereka memiliki karakteristik, permasalahan dan kebutuhan yang berbeda-beda, yang tidak mungkin ditangani melalui proghram yang sifatnya top-down dan seragam; (2) Program yang dikembangkan lebih banyak bersifat darurat-penyelamatan yang justru beresiko mematikan potensi self-help penduduk miskin untuk menolong dirinya sendiri, dan (3) Program pemberdayaan usaha yang ditekuni masyarakat miskin lebih banyak berupa penyaluran bantuan modal usaha, tanpa memperhitungkan iklim persaingan usaha yang makin kompetitif dan daya beli masyarakat yang menurun.

Diakui atau tidak, selama ini berbagai program penanggulangan kemiskinan yang digulirkan terutama dalam bentuk pemberian subsidi yang karitatif dan bantuan modal usaha atau pembinaan usaha produktif keluarga miskin-- seringkali masih terkonsentrasi pada rekayasa yang sifatnya teknis produksi dan cenderung hanya beriorientasi kuantitas, sehingga dalam banyak hal lebih menguntungkan kelompok masyarakat yang memiliki modal dan asset produksi yang berlebih. Ke depan, untuk mencegah agak tidak lagi terperosok pada kekeliruan yang serupa, dan upaya pemberdayaan masyarakat miskin di Kota Bontang melalui Program CSR benar-benar dapat berjalan efektif, maka yang dibutuhkan bukan sekadar kesediaan untuk melakukan introspeksi, tetapi juga revitalisasi program pemberdayaan masyarakat miskin yang benar-benar kontekstual dan berpihak kepada lapisan yang paling miskin khususnya para pelaku ekonomi kerakyatan. Kemudian ada stategi dan rekomendasi program CSR prioritas yang harus dilakukan sebagai upaya penanggulangan kemiskinan di Kota Bontang.

\section{Daftar Pustaka}

Amba-Rao SC (1993) Multinational corparate social responsibility, ethics, interactions, and third world government: An agenda for the 1990s. Journal of Business Ethics, 12(7)553-572.

Anderson JJW (1989) Corporate Social Responsibility: Guidlines for Top Management. New York: Quorum Books. 
Elkington J (1997) Cannibals with Forks: The Triple Bottom Line of Twentieth Century Busniness. Oxford (UK): Capstone Publishing.

Ife J \& Frank T (2008) Alternatif Pengembangan Masyarakat di Era Globalisasi, Community Development. Yogyakarta: Pustaka Pelajar.

Jalal (2006) Menimbang CSR Secara Rasional. Dalam: Kompas, September 2006.

Kim KS (2000) Corporate Social Responsibility and Strategic Management: An Empirical Study of

Korean MNCs in the United States. Unpublished Dissertation. West Heaven, Connecticut: The University of Heaven.

Raynard P \& Forstater M (2002) Corporate Social Responsibility: Implications for Small and Medium Enterprises in Developing Countries, Reports, United Nations Industrial Development Organization, Vienna.

Suharto \& Edi (2005) Membangun Masyarakat, Memberdayakan Rakyat, Kajian Strategis Pembangunan Kesejahteraan Sosial \& Pekerjaan Sosial. Bandung: Refika Aditama.

Suharto \& Edi (2007) Kebijakan Sosial, Sebagai Kebijakan Publik. Bandung: Alfabeta.

Suharto \& Edi (2007) Pekerjaan Sosial di Dunia Industri, Memperkuat Tanggungjawab Sosial Perusahaan Corporate Social Responsibility. Bandung: Refika Aditama.

Suharto \& Edi (2008) CSR: What is and Benefits for Corporate. Dalam: Majalah Bisnis dan CSR 1(4). Sunyoto S (2012) Budgeting Perusahaan: Teori, Kasus \& Soal Latihan. Jakarta (ID): PT Buku Seru. Wibisono \& Yusuf (2007) Membedah Konsep \& Aplikasi CSR. Gresik Fascho Publishing. 